\title{
MINIMIZING THE RATE OF STUDENTS DEVIANT BEHAVIOURS THROUGH INSTRUCTION IN SOCIAL STUDIES IN EKITI AND ONDO STATES, NIGERIA
}

\author{
Dr. (Mrs.) F.M. Osalusi \\ Department of Educational Foundations and Management \\ Ekiti State University, Ado-Ekiti, Nigeria \\ e-mail: osalusiflo2009@gmail.com \\ Corresponding Author \\ \& \\ Prof. G. Olu Oyinloye \\ Department of Curriculum Studies \\ Ekiti State University, Ado-Ekiti, Nigeria. \\ e-mail: olugaby33@yahoo.com
}

\begin{abstract}
This study examines the need to reduce deviant behaviours among junior secondary schools through the teaching of Social Studies. Deviant behaviours manifest in many ways among the junior secondary school students in Nigeria. The impact of such behaviour is not only felt in the academic achievement of students but also manifests in the social vices committed by these students in the community. This study raises question about the nature of deviant behaviours manifested by these students and also raises questions about the causative factors and the influence of Social Studies instruction in minimizing the rate of deviant behaviours among the students. The population of the study is the Social Studies teachers in Ekiti and Ondo States Secondary Schools. The sample consists of One hundred and fifty teachers of Social Studies selected through random sampling technique from Ekiti and Ondo States. Two research questions and two hypotheses were formulated for the study. The Instrument for the study was a questionnaire designed for teachers. The questionnaire elicits information on the teachers' perception on if Social Studies instruction could serve as a means of reducing student's deviant behaviours. The data collected from the respondents were analysed using t. test statistics. It was found that teachers perceived that the deviant behaviours of the students will reduce significantly if they were taught Social Studies contents in school specifically in its areas that teach morals and culture. It was therefore recommended that the teachers should emphasise the lessons derived from the teaching of any Social Studies concepts in the secondary school.
\end{abstract}

Keywords: reduction; social vices; perception; moral; truancy; instruction.

\section{Council for Innovative Research}

Peer Review Research Publishing System

\section{Journal: Journal of Social Science Research}

Vol. 4, No. 3

Jssreditor.cir@gmail.com

www.jssronline.com 


\section{INTRODUCTION}

The issue of deviant behaviour among junior secondary school students in Ekiti and Ondo States Nigeria has become worrisome in recent times. Teachers and some stake holders in Education have observed the increase in the rates of deviant behaviours among secondary school students. The effects of these behaviours seem to have impact on the academic achievement of the students and the society at large. It is observed that if students are exposed to a subject that will teach them about moral and .cultural values with emphasis on the ability and need to transfer the learnt behaviours to real life situation, there could be changes in the rate of deviant behaviours among the students. The teaching of Social Studies in this situation is not only to make the students become familiar with the academic contents but to let them understand the values inherent in the subject as well as learn about the application of these to real life situation. It must be noted that the needs of the students as well as their communities must be considered and equally be related to the teaching of Social Studies contents if the above objective will not be compromised.

[5] observed that Nigeria has above 250 ethnic groups, each with its own identity and value systems while the society is bedevilled by indiscipline and social vices. She concluded that Social Studies instruction can help young learners to understand the problem of his society and learn to be a disciplined individual. On the issues of the values of Social Studies to the society, [1] says that Social Studies instruction could help individual members of a society to develop the ability to adapt to their ever-changing environments and produce citizens who will be loyal, obedient, honest and hardworking. Social Studies instruction is therefore relevant to the needs of the children. For instance, students are exposed to too much information in this century and some of the information learnt through many sources are at variance with their cultural values. In other words, the ideas and knowledge acquired through internet, films and reading may impact wrong education to students.

Contributing to the issue of societal problems, [7] observed that today's world faces many difficult problems especially crime, drug abuse, domestic and workplace violence, gang activity and vandalism, school dropouts and broken families. Education is expected to help the recipients to develop good character and to minimise these problems, Social Studies instruction in the elementary and junior secondary schools should be taken seriously. To this end, [3], observed that students cannot understand the world without the knowledge of other people on the planet. They observed that there are profound differences between what is taught about world's cultures in American classrooms and the live experiences, beliefs and world views of people in those cultures. Therefore, teachers should make sure that what they are teaching the learners are the true reflections of the culture being taught to the learners. [3] concluded that students should be taught culture because it includes the shared assumptions, values and beliefs of a group of people and shape their norms of behaviour, world views and use of technology.

It is observed that many students are found to disobey school rules and regulations, engage in drug abuse, truancy, raping, pilfering, abortion and having unlawful association. Some of these students are sexually precocious, indolent and disobedient to parents, found of destroying public properties especially when they are used by adults in protests. In the process of being deviant, many children of school age dropped out of the school only to become hoodlums and miscreants in the society. Another worrisome situation is the neglect of parents' roles by modern parents. Many parents nowadays have left their responsibilities for the teachers. [6] observed that one of the reasons usually given for the neglect of parental roles is that many parents give much priority to their occupation at the expense of their children, hence, they are left to the care of teachers. Since, students often experience different people with different types of behaviours in their daily lives, they therefore tend to display different characters in different situations. Sometimes they are exited, happy, aggressive, sad or in a deviant mood. When deviant behaviour is identified it needs to be dealt with immediately.

[2] observes that the neglect of Social Studies instruction in schools most especially in Nigeria is alarming and raises questions about how young people learn about their social and environmental world and prepare to become tolerant, fully and positively engaged as critical citizens of a democratic society in interdependent world. [4] says that denying students access to Social Studies in the elementary grades has broad ramifications because young people in these grades must learn the roles of democratic citizenship and also develop the knowledge and skills that are foundational to later learning so that they can develop democratic ideas, civic skills, human value and dispositions of care for the environment each of which is critically important for acquiring the moral and ethical sensibilities necessary for the $21^{\text {st }}$ century.

National Policy for Integrated Early Childhood Development in Nigeria (2009) identified the fact that the average Nigerian child is highly deprived in terms of good health, proper care, education and rights to basic requirements of life. This observation is a serious issue and can lead to an increase in the rate of deviant behaviours among children who experience deprivation in terms of good care and basic requirements of life. Other challenging situations that influence deviant behaviours among the secondary school students are the peer influence. These students learnt a lot of things about life through peers at times more than they learn in the classrooms and from their parents. In some cases knowledge gained from the peers has negative impact on the behaviour of the students. The researchers are of the opinion that, the impact of the resultant negative behaviours demonstrated by students could be reduced if they were exposed to some aspect of Social Studies instruction that will teach the impact of peer group influence. This study has its focus on the reduction of the rate of deviant behaviours among secondary school students through the teaching of Social Studies. 


\section{Research Question and Hypotheses}

In order to carry out this investigation, two research questions were generated. These are:

i. Will there be any difference in the reduction in the rate of deviant behaviours among secondary school students if they were exposed to instruction in Social Studies.

ii. Will there be any difference in the rate of social vices committed by secondary school students if they were exposed to instruction in Social Studies.

These research questions were translated to research hypotheses as follows:

i. There will be no significant difference in the rate of deviant behaviours demonstrated by the secondary school students exposed to Social Studies instruction and those not exposed.

ii. There will be no significant difference in the rate of social vices committed by secondary school students it they were exposed to instruction in Social Studies.

\section{Method of Study}

The study is a descriptive one using survey methods. It uses questionnaire to elicit information from the responds. The population of the study is the Social Studies teachers in Ekiti and Ondo States Nigeria. The sample consists of one hundred and fifty teachers who teach Social Studies in the secondary schools.

\section{Research Instrument}

The research instrument is a questionnaire designed to elicit information on the teachers' perception on minimising the rate of deviant behaviours and social vices through instruction in Social Studies. (TPMRDBTIS). The questionnaire has thirty items which elicit information on teachers' bio-data, and their perception on some aspects of Social Studies instruction, specifically aspects that teach moral and social behaviour and culture. The deviant and social vices investigated are, disobeying rules and regulation of the school, unlawful association and gangs, drug abuse, truancy, raping, pilfering, abortion, sexually precocious, indolent, and disobedient to parents, thuggery and destruction of public property.

\section{Validity and Reliability of the Instrument}

The questionnaire was given to experts in Social Studies to ascertain the content and face validity. The reliability of the instrument was established through test and retest method. The instrument was administered on fifty Social Studies teachers and the data was analysed and subjected to Pearson Product Moment Correlation. The result yielded a correlation coefficient of 0.75 which was good enough for the study.

\section{Administration of the Study}

The instrument was administered on one hundred and fifty Social Studies teachers who filled the questionnaire. The questionnaires were collected immediately they were filled. The data collected were analysed and subjected to t-test statistics. The results are as shown below.

\section{Results}

The first hypothesis stated that there is no significant difference in the rate of perceived deviant behaviours demonstrated by the secondary school students exposed to Social Studies instruction and those not exposed.

Table I: Summary of t-test statistics on perceived influence of Social Studies on students deviant behaviour

\begin{tabular}{|c|c|c|c|c|c|c|c|}
\hline Source of variation & $N$ & Mean & $S D$ & $d f$ & t-cal & t-table & Remarks \\
\hline $\begin{array}{l}\text { Student exposed to social study } \\
\text { instruction }\end{array}$ & 150 & 32.900 & 5.894 & \multirow{2}{*}{149} & \multirow{2}{*}{4.207} & \multirow{2}{*}{1.96} & \multirow{2}{*}{ Significant } \\
\hline $\begin{array}{l}\text { Students not exposed to social } \\
\text { study instruction }\end{array}$ & 150 & 29.8400 & 5.948 & & & & \\
\hline
\end{tabular}

The table above shows that the $\mathrm{t}$-cal is 4.207 while $\mathrm{t}$-table is 1.96 . The calculated value is greater than the table value therefore the hypothesis is not accepted. This implies that there is significant difference in the perceived deviant behaviour of secondary school students if they were exposed to Social Studies instruction.

Hypothesis two stated that there will be no significant difference in the rate of social vices committed by students who were exposed to Social Studies instruction and those who were not. 
Table II: Summary of t-test showing differences in minimising the vices committed by students if they were taught Social Studies

\begin{tabular}{|c|c|c|c|c|c|c|c|}
\hline Source of variation & $N$ & Mean & $S D$ & $d f$ & $t$-cal & t-table & Sig. \\
\hline Students taught & 150 & 32.945 & 5.947 & & & & \\
\hline Not taught & 150 & 30.753 & $5 . .841$ & 149 & 3.040 & 1.96 & Significant. \\
\hline
\end{tabular}

The table above shows that the t-calculated 3.04 is greater than the table value 1.96 . This implies that there is significant difference between the students who were taught Social Studies and those who were not. Therefore the null hypothesis is not accepted.

\section{Discussion}

This study investigated whether the rate of deviant behaviours of junior secondary school students can be minimised through instruction in Social Studies in Ekiti and Ondo States. The findings from the study show that if students were exposed to the contents of Social Studies in the areas of moral, culture and environment, the rate of deviant behaviours among the youths might reduce. This finding corroborates the observation of [2] that Social Studies instruction will prepare children to become tolerant, good citizens, develop democratic values and fully integrated into their society. The students will also understand what good governance entails and as well understand their roles as good citizens. They may likely shun politicians who may want to use them as thugs during election.

The study also found that Social Studies instruction could lead to reduction in social vices usually committed by the students. This also corroborates the observation of [4], that Social Studies instruction will help the children to learn the roles of democratic citizenship and also develop the knowledge and skills that are foundational to later learning so that they can develop democratic ideas, civic skills, human values and disposition of care for the environment. The findings of the study also revealed that Social Studies instruction will avail the students the opportunity to acquire the moral and ethical sensibilities necessary for full integration into this 21 st century society. The study also found that Social Studies instruction could assist in reducing the stress on teachers when most of the students are well disciplined and cultured. This is very important because teachers will be able to do their best if they are not working under a stressful environment.

\section{Conclusion and Recommendations}

The study concluded that Social Studies instruction is very important to the development of good moral and ethical social behaviour. It is also observed through the study that Social Studies instruction could serve as foundation for further learning if properly handled. Instruction in Social Studies can also shape the moral standard of pupils by making them become honest and reliable individuals. As a result of the findings of the study, it is recommended that students at the Junior Secondary School should not be denied Social Studies instruction because of its numerous advantages.

\section{REFERENCES}

[1] Anders, W. 2010. Engaging pedagogies in elementary Social Studies. USA: National Council for Social Studies.

[2] Cole, B. 2010. Engaging pedagogies in elementary Social Studies. In E. Margit and Bronwyn Cole, Making a difference: Revitalizing elementary Social Studies. Maryland: National Council for Social Studies.

[3] Merryfield, M. M. and Wilson, A. 2005. Social Studies and the world teaching global perspectives. Maryland: National Council For Social Studies.

[4] McGuire, E. and Cole, B. 2010. Making a difference: Revitalizing elementary Social Studies. Maryland: National Council for Social Studies.

[5] Osalusi, F. M. 2010. Social Studies education and Nigeria quest for self reliance. Journal of the Faculty of Education (UNADJOE), University of Ado-Ekiti. 5(1).

[6] Oyinloye, G. O. and Osalusi, F. M. 2013. Critical literacy and Social Studies: Panacea to peaceful co-existence. In Literacy and Reading, Journal of the Reading Association of Nigeria. 14(1).

[7] Yusuf, H. 2010. The need for character training curriculum: A reform in curriculum for basic education in Nigeria. Journal of the Faculty of Education (UNADJOE), University of Ado-Ekiti. 5(1). 